\title{
The Effect of School Principals' Distributed Leadership Behaviours on Teachers' Organizational Commitment
}

\author{
Rezzan UÇAR ${ }^{1}$ \\ ${ }^{1}$ Faculty of Education, Van Yuzuncu Yil University, Van, Turkey \\ Correspondence: Rezzan UÇAR, Faculty of Education, Van Yuzuncu Yıl University, Van, Turkey. E-mail: \\ ucarrezzan@gmail.com
}

Received: December 16, 2020

Accepted: February 2, $2021 \quad$ Online Published: April 25, 2021

doi:10.5539/ies.v14n5p19

URL: https://doi.org/10.5539/ies.v14n5p19

\begin{abstract}
The purpose of the study is to explore the effect of school principals' distributed leadership behaviours on teachers' organizational commitment in the views of teachers employed in high schools. The study is a descriptive research designed as a correlational survey model and the research population consists of teachers in high schools in the provincial centre of Diyarbakır, a large city in south-eastern Turkey. The study is conducted with 275 teachers, selected by simple random selecting method. In the research, conducted in the views of high school teachers, descriptive statistics are employed to determine the distributed leadership behaviours of the participant principals and the teachers' organizational commitment levels and a regression analysis is used to predict the participant teachers' organizational commitment arising from the distributed leadership behaviours of the school principals. As a result of the study, the distributed leadership behaviours of the school principals are found at a high level in the following factors: open leadership, school culture, employee involvement and dynamics, whereas the teachers' organizational commitment levels are found low in the compliance factor but as for identification and internalisation factors, they are found high. Moreover, it is determined that teachers' organizational commitment can be statistically predicted from school principals' distributed leadership behaviours.
\end{abstract}

Keywords: distributed leadership, organizational commitment, high schools

\section{Introduction}

With the latest advances, schools with certain capacities have had their own developmental issues, which brings leadership on the agenda at all education levels (Hallinger \& Heck, 2009) as leadership needs various fields of specialisation to meet changes and innovations in the complicated world of education and the established organizational structures of schools have failed to meet learning needs in the $21^{\text {st }}$ century (Harris \& Spillane, 2008). As a result of research on school development, it is obvious that the traditional one-man in power concept has been attached less importance and teacher group activities or collective responsibilities have been considered more significant, instead. One of the leadership models which researchers have developed as an alternative to the traditional leadership approaches is distributed leadership (Lima, 2008).

Distributed leadership is a kind of leadership that focuses on interaction rather than formal and informal leadership role actions (Harris \& Spillane, 2008). It is one of the modern leadership approaches, and from its perspective, leaders need to work with groups instead of single performance and distributive responsibility highlights the significance of the following terms: teamwork building and shared responsibility (Chang, 2011). Distributed leadership means many leaders and a shared leadership activity in an organization (Harris \& Spillane, 2008).

Chang (2011) has subdivided the distributed leadership as; open leadership, the dynamism and the participation of the members and the atmosphere of the situation. On the other hand, Uçar (2015) suggested three dimensions for the distributed leadership; open leadership, school culture and employee involvement and dynamism. Open leadership is described as by giving up the necessity of controlling, having confidence and being unpretentious, and encouraging people to reach and dedicate their aims $(\mathrm{Li}, 2011)$. Distributed leadership is a kind of leadership that the power of leadership is not concentrated in one hand, but all the employees have a say in leadership activities. Considering this, it requires being open to all elements around. School culture is defined as a shared administrative system that holds all the units together and having them achieved a distinctive identity (Hoy \& Miskel, 2010). Distributed leadership is related with the executive leaders' having an initial duty to improve the people's knowledge and skills, creating a common culture around the usage of this knowledge and skills, providing 
an organization atmosphere that everyone has an effective relation and giving responsibilities to people for contribution to the total results (Elmore, 2000). Employee involvement and dynamism is described for participation as a group administration type that is consist of people who take the responsibility in managerial decisions (Eren, 2008) and for dynamism as the process of mutual interaction (Eren, 2008). In distributed leadership additional dynamics are created by bringing initiative and expertness of people together (Jappinen, 2012). Considering all this together, it can be suggested that in distributed leadership open leadership understanding, the culture that gains importance by people's communication, participation and dynamism of the observers become important (Uçar \& Dağl1, 2017).

The educational definition of distributed leadership, which attracts the attention of executives, experts, policy makers and researchers (Spillane \& Diamond, 2007; Spillane \& Orlina, 2005), is beyond most leadership definitions in education. When the literature is reviewed from school principals' perspective, they are supposed to have all the necessary skills and capabilities to eliminate all drawbacks in their own schools. They are obliged to keep in-school or out-of-school close contacts with employees, act as human relations experts, assist all disagreements arising between any persons that could lead to conflicts among students, teachers and in the school environment, act respectfully to manager authority and keep alert for administrative violations that could disturb teacher autonomy and establishing a steady school environment (Elmore, 2000) and many other things. In other words, principals have all managerial and political responsibilities and it is becoming more and more complicated to fulfil these responsibilities (Grubb \& Flessa, 2009). However, research has shown that school leadership is not an arena where school principals can act on their own, and that teacher leaders and other experts have a crucial role in educational innovation orientation (Spillane, Halverson and Diamond, 2004). In this context, distributed leadership introduces a new perspective on leadership practices in schools (Harris, 2007).

Distributed leadership requires certain individuals to have responsibilities for organizational administration and orientation in performance-cantered effective management practices. It does not mean no one is responsible for the overall organizational performance (Elmore, 2000). In distributed leadership, the focal point is teams instead of single heroic leaders, and teachers, employees and students are considered as leaders each (Harris \& Spillane, 2008). It is particularly aimed at the exploration of teachers' different roles in classrooms and school goal attainment, and at various task delegations (Louis, Mayrowetz, Smiley, \& Murphy, 2009). In this context, distributed leadership reflects a new conceptualisation attempt to understand how school leadership might be distributed in the scope of role diversity and explore the leadership process (Firestone \& Martinez, 2009).

Distributed leadership is a beneficial method in that teachers get school-related responsibilities and thus a sense of involvement in the leadership process (Hammersley-Fletcher, 2004). It is likely that the quality of decisions will increase when more teachers get involved in the decision-making process as they are well aware of the needs of their students and colleagues. When an insider who knows classroom practices gets involved in decision making, this will allow the process to result in better quality outputs (Chamberland, 2009). Increased involvement in the decision-making process might improve commitment to organizational goals and strategies (Leithwood, Mascall, \& Strauss, 2009). Therefore, in ensuring the organizational commitment of teachers, the importance of administrators to display distributed leadership behaviours becomes apparent.

Organizational commitment is defined as a view that is shaped in parallel with employee-organization relationship and that influences individual decisions to remain employees of their current organizations, as a result of the shaping process (Allen \& Meyer, 1990) or in other words, as the extent of individual integration into organizations (Balay, 2000). Considering organizational commitment as individuals' psychological commitment to their own organizations, O'Reilly III and Chatman (1986) discusses organizational commitment under three factors: compliance, identification, and internalisation. Compliance means superficial commitment of employees to organizations. The primary aim here is to attain personal interests and gains. In identification, an employee respects organizational values, tries to attain these and is proud being an organizational member. Internalisation is completely based on shared personal and organizational values.

Organizational commitment is influenced by personal factors and in-organization and out-of-organization factors. Organizational achievement depends on increased organizational commitment of employees (Ince \& Gül, 2005). In this context, it can be suggested that teachers' organizational commitment is significant in terms of school goal attainment.

With various responsibilities, teachers are the core of an education system. General school performances may depend on teachers' organizational commitment. In this context, teachers' commitment is an important issue not only for teachers, but also for schools and students (Tadesse, 2019). A teacher's organizational commitment affects the success of teaching and teachers' responsibility for work-related fulfilment. When a teacher shows 
organizational commitment, this might influence students' academic achievement and learning (Aslamiah, 2019). Teachers' organizational commitment affects many factors in schools, and similarly many organizational factors could influence teachers' organizational commitment levels. It might be suggested that one of those factors is leadership styles of school principals.

The research results show that there has been a relationship between leadership style and employees' organizational commitment (Ceylan, Keskin, \& Eren, 2005; Çakınberk \& Demirel, 2010; Çekmecelioğlu, 2014; Doğanay \& Şen, 2016). In this context, it is pointed out that leadership features influences teachers' organizational commitment (Bektaş, Çoğaltay, \& Sökmen, 2014). Research has also shown that certain leadership types positively correlated with organizational commitment (Geijsel, Sleegers, Leithwood, \& Jantzi, 2002; Buluç, 2009; Yavuz \& Tokmak, 2009; Şama \& Kolamaz, 2011; Uygur \& Yıldırım, 2011; Aytaç, 2015; Dou, Devos, \& Valcke, 2016). When leaders are considered as participants, employees feel more committed to organizations and it results in better job satisfaction and staff performance (Bogler \& Somech, 2004). As distributed leadership inholds shared experiences, collaboration, democracy and involvement (Harris, 2008), it is thought that distributed leadership behaviours of school principals could be associated with teachers' organizational commitment levels. In this context, the study on the exploration the effect of high school principals' distributed leadership behaviours on teachers' organizational commitment is expected to contribute to the literature.

\subsection{Purpose}

The research aimed to explore the effect of high school principals' distributed leadership behaviours on teachers' organizational commitment in the views of teachers employed in high schools. Bearing this purpose in mind, answers to the following questions were sought:

1) At what level are school principals' distributed leadership behaviours?

2) At what level is teachers' organizational commitment?

3) Could teachers' organizational commitment levels be predicted by school principals' distributed leadership behaviours?

\section{Method}

Information on the research, which was designed as a correlational survey model, is presented under the sub-headings below: sampling, data gathering instruments and data analysis.

\subsection{Sampling}

The study was conducted with teachers employed in high schools in the following central districts of Diyarbakır province; Bağlar, Kayapınar, Sur and Yenişehir. Considering the difficulty of reaching all the teachers in the research population, 16 high schools chosen by simple random sampling method to represent the population according to the districts ( 4 high schools from each of the districts were chosen by simple random selecting method). Tobe a participant of the research was based on volunteering, and thus a total of 320 teachers were reached. Out of 292 measurement tools that were sent back, 275 forms which had been answered according to the instruction were evaluated. 103 (37.5\%) of the participant teachers were female and $172(62.5 \%)$ were male. 214 (77.8\%) participants were married, and 61 (22.2\%) participants were single. 178 (64.7\%) of the participants were employed in high schools and 97 (35.3\%) in vocational and technical high schools. Professional seniority of the participant teachers ranged from 1 to 34 years.

\subsection{Data Gathering Instruments}

The "Distributed Leadership Scale", developed by Uçar (2015) and the "Organizational Commitment Scale", developed by Balay (2000) and the reliability and validity analyses of which were reperformed by Erdem (2008), were incorporated in the study as data gathering instruments.

Distributed Leadership Scale consists of 37 items and the following three factors: open leadership, school culture and employee involvement and dynamism. Since the scale was initially developed for primary school teachers (Uçar, 2015), validity and reliability study of the scale was reperformed to see whether it varied in high school teachers. As a result of the validity analysis, it was concluded that the scale supported the original structure. In this context, the scale was grouped under three factors and the item placement remained the same in the factors. Accordingly, the factor ranges were defined as follows: the first factor between item 1 and item 14, the second between item 15 and item 28 and the third between item 29 and item 37 . The first factor explained $26 \%$ of the variance, the second explained $21 \%$ and the third explained $20 \%$. Item factor loadings were found to range from .60 to .79 for the first factor, from .54 to .73 for the second and from .71 to .81 for the third. The Cronbach's alpha coefficient was examined for the reliability of the scale. In the original scale, the Cronbach's alpha 
coefficient was $\alpha=.95$ for open leadership, $\alpha=.96$ for school culture and $\alpha=.94$ for employee involvement and dynamism. In this study, however, the Cronbach's alpha coefficients were found $\alpha=.96$ for open leadership, $\alpha=.97$ for school culture and $\alpha=.95$ for employee involvement and dynamism.

Organizational Commitment Scale consists of 24 items and three factors: compliance, identification and internalisation. There was no need to reperform validity analysis since the structural validity of the scale for high school teachers was tested by Balay (2000) and retested by Erdem (2008). The Cronbach's alpha value was examined for the reliability of the research. In the original scale (Balay, 2000), the Cronbach's alpha value was $\alpha$ $=.79$ for the compliance factor, $\alpha=.89$ for identification and $\alpha=.93$ for internalisation. In the scale for which the factor analysis was reperformed by Erdem (2008), the Cronbach's alpha value was $\alpha=.76$ for the compliance factor, $\alpha=.91$ for identification and $\alpha=.92$ for internalisation. In this research, the Cronbach's alpha values were found $\alpha=.87$ for the compliance factor, $\alpha=.90$ for identification and $\alpha=.77$ for internalisation.

\subsection{Data Analysis}

During the data analysis process in SPSS, it was attempted to define the perceptions of the participant teachers about the factors of the distributed leadership and organizational commitment scales by arithmetic mean and standard deviation. The research data were primarily examined to see whether they were normally distributed by checking skewness and kurtosis values, Q-Q graphics (Q-Q Plot) and histogram graphics in order to understand if the research data were eligible for a regression analysis. As a result of the performed analysis, the skewness values of the variables ranged from -1.03 to 1.12 and the kurtosis values ranged from -.05 to 1.31. It is assumed that distribution is normal when skewness and kurtosis values range from -1.5 to +1.5 (Tabachnick \& Fidell, 2013). The Q-Q and histogram graphics also showed that the variables met the normal data distribution assumption (Baykul \& Güzeller, 2014; Can, 2014). After the examination of the normal distribution of the research data, auto-correlation was checked with suspicion. Any auto-correlation under suspicion is tested by Durbin Watson analysis. The more the auto-correlation suspicion for the multiple linear regression models vanishes, the closer the Durbin-Watson value is to 2 (Doğan \& Yllmaz, 2017). In this research, the Durbin-Watson values were found 1.92, 1.88 and 1.82 . This result might be interpreted as there is no auto-correlation obtained. One of the assumptions to meet in order to perform a regression analysis and to accurately interpret obtained findings is that there must be a robust correlation between independent variables since any multicollinearity issues that may arise could lead to misinterpretations of a regression equation. There are various methods to decide whether there is multicollinearity in a regression model. One of these methods is the examination of Variance Inflation Factor (VIF) values. If VIF values are higher than 5 and 10, multicollinearity could be mentioned (Doğan Başokçu \& Doğan, 2005; Zırhlıoğlu \& Atl1, 2011). A likely multicollinearity was examined in the study by calculating the VIF values of the obtained data. All the analyses showed that the data set was eligible for a regression analysis. Accordingly, multi regression analysis was used to decide whether the participant teachers' organizational commitment levels could be predicted from the school principals' distributed leadership behaviours.

\section{Findings}

In this section, the findings obtained as a result of analysing the gathered data by using the above mentioned techniques in accordance with the research purpose are presented. In this context, the participant teachers' perceptions about the school principals' distributed leadership behaviours were primarily handled under the following factors: open leadership, school culture and employee involvement and dynamism, and their own organizational commitment under the following factors: compliance, identification and internalisation. Then, a regression analysis was employed to decide whether compliance, identification and internalisation factors of organizational commitment could be predicted by the school principals' distributed leadership behaviours.

Means of the participant school principals' distributed leadership behaviours and the teachers' organizational commitment levels in consideration with the factors are presented in Table 1.

Table 1. Means and standard deviation scores of distributed leadership factors and organizational commitment

\begin{tabular}{llcccc}
\hline Scale & Factor & $\mathrm{n}$ & $\bar{X}$ & $\mathrm{ss}$ & Level of Agreement \\
\hline \multirow{4}{*}{ Distributed Leadership } & Open leadership & 275 & 3.94 & .846 & I strongly agree \\
& School culture & 275 & 3.80 & .870 & I strongly agree \\
& Employee involvement and dynamism & 275 & 3.80 & .829 & I strongly agree \\
\hline \multirow{3}{*}{ Organizational Commitment } & Compliance & 275 & 2.04 & .931 & I slightly agree \\
& Identification & 275 & 3.57 & .931 & I strongly agree \\
& Internalisation & 275 & 3.83 & .827 & I strongly agree \\
\hline
\end{tabular}


As it is clear in Table 1, the perceptions of the participant teachers employed in high schools about the school principals' distributed leadership behaviours are as follows: 3.94 in open leadership, 3.80 for school culture and employee involvement and dynamism. The teachers agree with the compliance factor of organizational commitment at the extent of 2.04 and it is 3.57 for identification and 3.83 for internalisation.

The study attempts to predict the compliance factor of organizational commitment of the participant teachers employed in high schools by the school principals' distributed leadership behaviours and the results of the regression analysis performed to that end are presented in Table 2.

Table 2. Results of regression analysis to predict teachers' views about compliance factor of organizational commitment from distributed leadership factors

\begin{tabular}{|c|c|c|c|c|c|c|c|}
\hline Variable & $\mathrm{B}$ & $\begin{array}{l}\text { Standard } \\
\text { deviation }\end{array}$ & $\beta$ & $\mathrm{T}$ & $\mathrm{p}$ & Binary $r$ & Partial r \\
\hline Fixed & 3.096 & .294 & - & 10.534 & .000 & - & - \\
\hline Open leadership & -.198 & .137 & -.180 & -1.448 & .149 & -.21 & -.09 \\
\hline School culture & .018 & .149 & .016 & .118 & .906 & -.20 & .01 \\
\hline Employee involvement and dynamism & -.091 & .091 & -.081 & -.999 & .319 & -.17 & -.06 \\
\hline
\end{tabular}

Note. $\mathrm{R}=.22 ; \mathrm{R}^{2}=.05 ; \mathrm{F}(3.273)=4.65 ; \mathrm{p}=.003$.

When Table 2 is examined, it is clear that the teachers' organizational commitment can significantly be predicted from their school culture perceptions in the compliance factor $(R=.22 ; F=4.65 ; p=.003)$. According to the regression analysis results, it is obvious that the teachers' perceptions about the open leadership, school culture and employee involvement and dynamism factors of school principals' distributed leadership behaviours explain 5\% of the variance in the compliance factor of organizational commitment. When the correlation between the teachers' perceptions about the compliance factor of organizational commitment and their perceptions about the open leadership, school culture and employee involvement and dynamism factors of distributed leadership is incorporatedly examined, it is observed that it is -.21 with open leadership, -.20 with school culture with and -.17 with employee involvement and dynamism. When the correlation between the factors of distributed leadership and the compliance factor of the teachers' organizational commitment is independently examined, it is seen that the correlation is $-.09(\mathrm{p}=.149)$ with open leadership, $.01(\mathrm{p}=.906)$ with school culture and -.06 with employee involvement and dynamism ( $\mathrm{p}=.319)$. According to the standardised regression coefficient, the relative order of significance of the predictive factors on the compliance factor of organizational commitment is as follows: school culture, employee involvement and dynamism and open leadership. When the t-test results of the significance of the regression coefficients are examined, it is clear that the distributed leadership factors do not have a significant influence $(p>.05)$ on the teachers' perceptions about the compliance factor of organizational commitment.

The study attempts to predict the identification factor of organizational commitment of the participant teachers from the school principals' distributed leadership behaviours and the results of the regression analysis performed to that end are presented in Table 3.

Table 3. Regression analysis results to predict identification factor of teachers' organizational commitment from distributed leadership factors

\begin{tabular}{|c|c|c|c|c|c|c|c|}
\hline Variable & $\mathrm{B}$ & $\begin{array}{c}\text { Standard } \\
\text { error }\end{array}$ & $\beta$ & $\mathrm{T}$ & $\mathrm{p}$ & $\begin{array}{c}\text { Binary } \\
r\end{array}$ & Partial r \\
\hline Fixed & .702 & .540 & - & 2.922 & .004 & - & - \\
\hline Open leadership & .369 & .112 & .336 & 3.309 & $.001 *$ & .57 & .20 \\
\hline School culture & .132 & .121 & .124 & 1.086 & .277 & .56 & .07 \\
\hline Employee involvement and dynamism & .240 & .075 & .214 & 3.221 & $.001 *$ & .49 & .19 \\
\hline
\end{tabular}

Note. $\mathrm{R}=.60 ; \mathrm{R}^{2}=.37 ; \mathrm{F}(3-274)=51.98 ; \mathrm{p}=.000 ; * \mathrm{p}<.05$.

In Table 3, it is clear that the perceptions of the teachers' employed in high schools about the identification factor of organizational commitment can statistically and significantly be predicted from their perceptions about the open leadership, school culture and employee involvement and dynamism factors of school principals' distributed behaviours $(R=.60 ; F=51.98 ; p=.000)$. When the regression analysis results are considered, it is clear that the 
teachers' perceptions about the open leadership, school culture and employee involvement and dynamism factors of school principals' distributed leadership behaviours explain $37 \%$ of the variance in the identification factor of organizational commitment. When the correlation between the teachers' perceptions about the identification factor of organizational commitment and the factors of distributed leadership is incorporatedly examined, it is observed that the correlation between identification and school culture is .57 , the correlation between identification and school culture is .56 and the correlation between identification and employee involvement and dynamism is . 49 . When the correlation between the factors of distributed leadership and identification is independently examined, it is seen that the correlation between open leadership and identification is $.20(\mathrm{p}=.001)$, the correlation between school culture and identification is .07 ( $\mathrm{p}=.277)$ and the correlation between employee involvement and dynamism and identification is $.19(\mathrm{p}=.001)$. According to the standardised regression coefficient, the relative order of significance of the predictive factors on the identification factor of organizational commitment is as follows: open leadership, employee involvement and dynamism and school culture. When the t-test results of the significance of the regression coefficients are examined, it is clear that the open leadership factor $(r=.57 ; p=.001)$ and the employee involvement and dynamism factor $(\mathrm{r}=.49 ; \mathrm{p}=.001)$ are significant predictors of identification. However, school culture factor $(\mathrm{r}=.56 ; \mathrm{p}=.277)$ does not have a significant influence.

The study attempts to predict the internalisation factor of organizational commitment of the teachers from the school principals' distributed leadership behaviours and the results of the regression analysis performed to that end are presented in Table 4.

Table 4. Regression analysis results to predict internalization factor of teachers' organizational commitment from distributed leadership factors

\begin{tabular}{|c|c|c|c|c|c|c|c|}
\hline Variable & $\mathrm{B}$ & $\begin{array}{c}\text { Standard } \\
\text { error }\end{array}$ & $\beta$ & $\mathrm{T}$ & $\mathrm{P}$ & $\begin{array}{c}\text { Binary } \\
\mathrm{r}\end{array}$ & Partial $\mathrm{r}$ \\
\hline Fixed & 1.802 & .235 & - & 7.658 & .000 & - & - \\
\hline Open leadership & .480 & .109 & .491 & 4.388 & $.000^{*}$ & .45 & .26 \\
\hline School culture & -.173 & .119 & -.182 & -1.456 & .147 & .39 & -.09 \\
\hline Employee involvement and dynamism & .209 & .073 & .209 & 2.857 & $.005 *$ & .37 & .17 \\
\hline
\end{tabular}

Note. $\mathrm{R}=.48 ; \mathrm{R}^{2}=.23 ; \mathrm{F}(3-274)=26.54 ; \mathrm{p}=.000 ; * \mathrm{p}<.05$.

In Table 4, it is clear that the perceptions of the participant teachers' employed in high schools about the internalisation factor of organizational commitment can statistically and significantly be predicted from their perceptions about the open leadership, school culture and employee involvement and dynamism factors of school principals' distributed behaviours $(R=.48 ; F=26.54 ; p=.000)$. When the regression analysis results are considered, it is clear that the teachers' perceptions about the open leadership, school culture and employee involvement and dynamism factors of school principals' distributed leadership behaviours explain $23 \%$ of the variance in the internalisation factor of organizational commitment. When the correlation between the teachers' perceptions about the internalisation factor of organizational commitment and the factors of school principals' distributed leadership behaviours is incorporatedly examined, it is observed that the correlation between internalisation and open leadership is .45 , the correlation between internalisation and school culture is .39 and the correlation between internalisation and employee involvement and dynamism is .37. When the correlation between the factors of school principals' distributed leadership behaviours and internalisation is independently examined, it is seen that the correlation between open leadership and internalisation is .26 ( $\mathrm{p}=.000)$, the correlation between school culture and internalisation is $-.09(\mathrm{p}=.147)$ and the correlation between employee involvement and dynamism and internalisation is $.17(\mathrm{p}=.005)$. According to the standardised regression coefficient, the relative order of significance of the predictive factors on the internalisation factor of organizational commitment is as follows: open leadership, employee involvement and dynamism and school culture. When the t-test results of the significance of the regression analysis are examined, it is concluded that the open leadership factor $(r=.45 ; \mathrm{p}=.000)$ and the employee involvement and dynamism factor $(\mathrm{r}=.37 ; \mathrm{p}=.005)$ are important predictors of internalisation. However, school culture factor $(\mathrm{r}=.39 ; \mathrm{p}=.147)$ does not have a significant influence.

\section{Results, Discussion, and Recommendations}

As a result of the study, the participant high school teachers think the principals' distributed leadership behaviours are at a high level in the following factors: open leadership, school culture, employee involvement and dynamism. This result could be interpreted as the fact that the teachers feel the school principals' show distributed leadership 
behaviours. In the $21^{\text {st }}$ century, organizations attempt to increase learning and innovative capacity along with the diversity of collaborative approaches and highlight information sharing when faced with organizational restrictions (Zhang \& Faerman, 2007). In this context, since school leadership is not an arena where school principals can act on their own, it is suggested that teacher leaders and other experts have a crucial role in educational innovation orientation (Spillane et al., 2004). Hence, teachers' views that school principals show distributed leadership behaviours could be positively interpreted in terms of the education system. There have been other studies on this issue with similar results. In their study, Uçar and Dağlı (2017) conclude school principals' display distributed leadership behaviours at a high level, Ereş and Akyürek (2016) find mostly and Baloğlu (2016) find such behaviours at a good level. Therefore it could be suggested that teachers think school principals' display distributed leadership behaviours. Studies conducted by Korkmaz and Gündüz (2011), Gökyer and Yılmaz (2018), Chang (2011), Silva (2009), Hulpia, Devos, and Russell (2009) also conclude that teachers think school principals show distributed leadership behaviours.

The participant teachers slightly agree with the compliance factor of organizational commitment, whereas they strongly agree with the identification and internalisation factors. In organizational commitment, the compliance factor means a superficial commitment and attitudes and behaviours show up as a result of reward-earning, not of shared beliefs. Identification is associated with personal acceptance of effects to maintain satisfying relationships. Internalisation is the result of the same personal and organizational values (O'Reilly III \& Chatman, 1986). In this context, the participant teachers' agreement with the compliance factor might be interpreted as a low-level superficial commitment. On the other hand, it might be concluded that they have a very high-level commitment caused by school relationships and personal-organizational value fit. In the literature, there has been research with relatively similar results. In studies by Akın and Orman (2015) and Kılıç and Burgaz (2014), the participant teachers slightly agreed with the compliance factor of organizational commitment, moderately agreed with identification and strongly agreed with internalisation. In another study by Balay, Kaya, and Karadaş (2017), the participant teachers' commitment levels were found insufficient in the compliance factor, moderate in the identification factor, and sufficient in the internalisation factor. A study by Ünal Bozcan and Yalçınkaya (2018) concluded that the participant teachers' commitment levels were found zero in the compliance factor, and high in the identification and internalisation factors. On the other hand, according to the findings of this study, the participant teachers agreed with the compliance the least, whereas they agreed with internalisation the most. Similar results were obtained in studies conducted by Balay (2000), Sezer (2005), Uygur and Yıldırım (2011), Erdem and Uçar (2013).

When the regression analyses are examined, it is concluded that teachers' commitment concerning compliance, identification and internalisation can statistically be predicted from their own perceptions about school principals' distributed leadership behaviours. A similar study conducted by Hulpia, Devos, and Keer (2010) shows that the distribution of the high-involvement decision making process and supportive leadership activity has a positive, significant influence on teachers' organizational commitment.

In the literature, there have been studies on the relationship between different types of leadership and organizational commitment. Buluç (2009) suggests a positive correlation between teachers' organizational commitment and school principals' transformational leadership behaviours. Serin and Buluç (2012) show a positive correlation between teachers' organizational commitment and school principals' instructional leadership behaviours, Şama and Kolamaz (2011) finds such a correlation with school principals' supporting and improving leadership features and Uğurlu, Sincar, and Çınar (2013) points out another with school principals' ethical leadership behaviours.

When the participant teachers' organizational commitment is examined under the factors, it is concluded that the compliance-based commitment can statistically be predicted from the school principals' distributed leadership behaviours. However, it is seen that the factors of distributed leadership do not have a great influence on teachers' perceptions about the compliance factor of organizational commitment. On the other hand, it is obvious that there is a low level negative correlation between the compliance factor of organizational commitment and the open leadership, school culture and employee involvement and dynamism factors of distributed leadership. This is an understandable result in that compliance-based commitment primarily aims at personal interests and gains (O'Reilly III \& Chatman, 1986), whereas in distributed leadership, leadership is the interaction between leaders, followers and conditions rather than one man's skills and capabilities, intelligence or charisma (Spillane et al., 2004). The primary goal to attain in distributed leadership is to create additional dynamics arising from individual sharing of initiatives, ideas and specialisation. In this way, an output greater than the overall individual acts appears. The process is built on a collaborative attitude and work manner (Jappinen, 2012). As a result, distributed leadership highlights teams rather than one heroic man and teachers, employees and students are considered as 
leaders each (Harris \& Spillane, 2008). When seen in this context, it seems natural that all the factors of distributed leadership and the compliance factor have been negatively correlated. Similarly, Şama and Kolamaz (2011) conclude that supporting and improving leadership behaviours and the compliance factor of organizational commitment are negatively correlated. Also, a study by Çokluk and Yılmaz (2010) suggests a negative correlation between school principals' supportive leadership behaviours and continuance commitment, which is thought to be similar to the compliance factor of organizational commitment.

In the study a moderate level correlation between the open leadership, school culture and employee involvement and dynamism factors of school principals' distributed leadership behaviours and the participant teachers' identification in organizational commitment is observed. It is also seen that the participant teachers' perceptions about the school principals' distributed leadership behaviours considerably explain the variance in the identification factor of teachers' commitment. It is concluded that the significantly influential factors of distributed leadership on the participant teachers' identification-based commitment are open leadership and employee involvement and dynamism. In identification-based commitment, employees tend to express themselves and thus get satisfaction by establishing close contacts with others (O'reilly III \& Chatman, 1986). Both open leadership, defined as encouraging people to ensure self-commitment for goal attainment, by giving up needs for monitoring and acting with self-confidence and modesty ( $\mathrm{Li}, 2011$ ), and employee involvement and dynamism, which highlights collaboration and mutual interaction between administrators and employees (Uçar, 2015) emphasize collaboration and interaction. Therefore, the resulting influences on identification are expected. Moreover, the focus in distributed leadership is on interaction rather than behaviours caused by formal and informal leadership roles (Harris \& Spillane, 2008). Such an interaction could be influential on identification-based commitment.

It is concluded that the participant teachers' internalisation-based commitment is moderately correlated with the open leadership, school culture and employee involvement and dynamism factors of school principals' distributed leadership behaviours. Moreover, the study shows that the participant school principals' distributed leadership behaviours considerably explain the variance in the teachers' internalisation-based commitment. Internalisation-based commitment is completely based on shared personal and organizational values. This kind of commitment appears when organizational values and those of employees are shared (O'Reilly III \& Chatman, 1986). Principals with open leadership behaviours are considered inspirational and catalytic to ensure individuals' collective sharing and output attainment $(\mathrm{Li}, 2011)$. This might provide a ground of shared values. On the other hand, when employees get involved in the decision-making process and become active, all organizational values might become easier to adopt as man tends to perform a decision to which he has contributed rather than an imposed one (Schein, 1976). Distributed leadership means many leaders and a shared leadership activity in an organization (Harris \& Spillane, 2008). In this context, the effect of the open leadership and employee involvement and dynamism factors of distributed leadership on internalisation-based commitment is quite understandable.

In this study, which examines the effect of school principals' distributed leadership behaviour on teachers' organizational commitment, the participant school principals' distributed leadership behaviours explain the identification-based commitment most, and the compliance-based commitment least. It is understandable that compliance-based commitment, in which reward-gaining or punishment avoidance are important rather than shared beliefs and values, is slightly influenced by distributed leadership. The reason for that is distributed leadership shifts leadership from role-centered attitudes or individualism (Firestone \& Martinez, 2009) to collective and social interactions (Bolden, Petrov, \& Gosling, 2009). Hence, leadership spreads through organizations shared by many members instead of one-man work and is built on interaction among various leaders (Hulpia, Devos, \& Keer, 2011). Distributed leadership in schools, however, is discussed as a collaborative practice by school principals, teachers and other members in development teams contributive to school improvements (Heck \& Hallinger, 2009). In this context, it is understandable that it has the greatest influence on the identification factor, in which employees are proud of organizational membership and attach importance to close contacts with others and self-expression.

The study has concluded that the participant school principals' distributed leadership behaviours predict the teachers' organizational commitment. In this context, frequent distributed leadership practices at schools and building a school environment that allows teachers' involvement and prioritises open leadership practices might increase teachers' organizational commitment. To that end, in-service training programmes are advisable for school principals to show how distributed leadership behaviours and distributed leadership practices in schools are accomplished. In such programmes, school principals might be provided with samples to enable them to display open leadership and act towards the elaboration of dynamics and involvement of school teachers. On the other hand, the study has been conducted with high school teachers. Further research might be carried out on the same issue at different school levels. This study has employed the qualitative method. Various methods or larger 
sampling groups might be examined in further research.

\section{References}

Akın, U., \& Orman, E. (2015). Öğretmenlerin örgütsel güven ile örgütsel bağlllık düzeyleri arasındaki ilişki. SDU International Journal of Educational Studies, 2(2), 92-102. Retrieved from https://dergipark.org.tr/tr/pub/sduijes/issue/20864/223882

Allen, N. J., \& Meyer, J. P. (1990). The measurement and antecedents of affective, continuance and normative commitment to the organization. Journal of Occupational Psychology, 63, 1-18. https://doi.org/10.1111/j.2044-8325.1990.tb00506.x

Aslamiah. (2019). Teachers organizational commitment in elementary school: a study in banjarmasin Indonesia. The Open Psychology Journal, 12, 1-6. https://doi.org/10.2174/1874350101912010001

Aytaç, T. (2015). The relationship between teachers' perception about school managers' talet management leadership and the level of organizational commitment. Eurasian Journal of Educational Research, 59(2015), 165-180. https://doi.org/10.14689/ejer.2015.59.10

Balay, R. (2000). Özel ve resmi liselerde yönetici ve ögretmenlerin örgütsel bağllll̆ğ Ankara İli örneği (Yayımlanmamış doktora tezi). Ankara Üniversitesi Eğitim Bilimleri Enstitüsü, Ankara.

Balay, R., Kaya, A., \& Karadaş, H. (2017). Pozitif okul yönetiminin öğretmenlerin örgütsel bağlılı̆̆ına etkisi. The Journal of Educational Reflections, 1(1), 1-12. Retrieved from https://dergipark.org.tr/tr/pub/eduref/issue/34202/378136

Baloğlu, N. (2016). Okul Müdürlerinin Dağıtımcı Liderlik Davranışları İle Kişilik Özellikleri Arasındaki İlişkiler. Kastamonu Eğitim Dergisi, 24(4), 1858-1866. Retrieved from https://dergipark.org.tr/tr/pub/kefdergi/issue/27734/327574

Baykul, Y., \& Güzeller, C. O. (2014). Sosyal bilimler için istatistik SPSS Uygulamalı. Ankara: Pegem Akademi. https://doi.org/10.14527/9786053644644

Bektaş, F., Çoğaltay, N., \& Sökmen, Y. (2014). Öğretmen algıllarına göre okul müdürlerinin liderlik stillerinin örgütsel bağll1lk üzerindeki rolü. Uluslararası Türk Eğitim Bilimleri Dergisi, 2(3), 122-130.

Bogler, R., \& Somech, A. (2004). Influence of teacher empowerment on teachers organizational commitment, professional commitment and organizational citizenship behavior in schools. Teaching and Teacher Education, 20, 277-289. https://doi.org/10.1016/j.tate.2004.02.003

Bolden, R., Petrov, G., \& Gosling, J. (2009). Distributed leadership in higher education. Educational Management Administration \& Leadership, 37(2), 257-277. https://doi.org/10.1177/1741143208100301

Buluç, B. (2009). Sınıf öğretmenlerinin algılarına göre okul müdürlerinin liderlik stilleri ile örgütsel bağll11k arasındaki ilişki. Kuram ve Uygulamada Eğitim Yönetimi, 15(57), 5-34.

Çakınberk, A., \& Demirel, E. T. (2010). Örgütsel bağlılığın belirleyicisi olarak liderlik: Sağlık çalışanları örneği. Selçuk Üniversitesi Sosyal Bilimler Enstitüsü Dergisi, 24, 103-119.

Can, A. (2014). SPSS ile bilimsel araşttrma sürecinde nicel veri analizi. Ankara: Pegem Akademi. https://doi.org/10.14527/9786053644484

Çekmecelioğlu, H. G. (2014). Göreve ve insana yönelik liderlik tarzlarının örgütsel bağlılık, iş performansı ve işten ayrilma niyeti üzerindeki etkileri. KOSBED, 28, 21-34.

Ceylan, A., Keskin, H., \& Eren, Ş. (2005) Dönüşümcü ve etkileşimci liderlik ile örgütsel bağll1ık arasındaki ilişkilere yönelik bir araştırma. Yönetim, 16(51), 32-42.

Chamberland, L. (2009). Distributed Leadership: Developing a New Practice an Action Research Study. Yayınlanmamış Doktora Tezi, University of California.

Chang, H. (2011). A study of the relationships between distributed leadership, teacher academic optimism and student achievement in Taiwanese elementary schools. School Leadership and Management, 31(5), 491-515. https://doi.org/10.1080/13632434.2011.614945

Çokluk, Ö., \& Yılmaz, K. (2010). The relationship between leadership behavior and organizational commitment in turkish primary schools. Bilig, 54, 75-92.

Doğan Başokçu, Ö., \& Doğan, N. (2005). Akademik benlik kavramı ölçeğinin ortaöğretim kurumları öğrenci seçme ve yerleştirme sınavını yordama geçerliği. Hacettepe Üniversitesi Eğitim Fakültesi Dergisi, 29, 
53-62.

Doğan, V., \& Yılmaz, C. (2017). Yönetim bilimleri ve pazarlama alanında bağımsız değişkenlerin karşılaştırılması ve bastırıcı etki tepkisi. Uluslararası Yönetim İktisat ve İşletme Dergisi, 13(2), 385-406. https://doi.org/10.17130/ijmeb.2017228690

Doğanay, A., \& Şen, E. (2016). Liderlik tarzlarının çalışanların bağlılık seviyesi ve performansına etkisi: Başakşehir belediyesinde bir uygulama. Yalova Sosyal Bilimler Dergisi, 7(12), 324-348. https://doi.org/10.17828/yalovasosbil.289026

Dou, D., Devos, G., \& Valcke, M. (2016). The relationship between school autonomy gap, principal leadership, teachers' job satisfaction and organizational commitment. Educational Management Administration \& Leadership, 45(6), 959-977. https://doi.org/10.1177/1741143216653975

Elmore, R. F. (2000). Building a new structure for school leadership. The Albert Shanker Institute.

Erdem, M. (2008). Öğretmenlere göre kamu ve özel liselerde iş yaşamı kalitesi ve örgütsel bă̆lılıkla ilişkisi (Yayımlanmamış doktora tezi). Ankara Üniversitesi Eğitim Bilimleri Enstitüsü, Ankara. https://doi.org/10.12738/estp.2013.3.1693

Erdem, M., \& Uçar, İ. H. (2013). Öğretmenlere göre ilköğretimde öğrenen örgüt algısı ve öğrenen örgütün örgütsel bağlılığa etkisi. Kuram ve Uygulamada Ĕgitim Bilimleri, 13(3), 1515-1534.

Eren, E. (2008). Örgütsel davranış ve yönetim psikolojisi. İstanbul: Beta Yayıncılık.

Ereş, F., \& Akyürek, M. (2016). İlkokul müdürlerinin dağıtılmış liderlik davranışları ile öğretmenlerin iş doyumu algıları arasındaki ilişki. Gazi Üniversitesi Gazi Ĕ̌itim Fakültesi Dergisi, 36(3), 427-449. Retrieved from http://www.gefad.gazi.edu.tr/tr/issue /29794/320356

Ergeneli, A. (2006). Örgüt ve insan. Ankara: Hacettepe Üniversitesi Yayınları.

Firestone, W. A., \& Martinez, M. C. (2007). Districts, teacher leaders, and distributed leadership: changing instructional practice. Leadership and Policy in Schools, 6, 3-35. https://doi.org/10.1080/15700760601091234

Geijsel, F., Sleegers, P., Leithwood, K., \& Jantzi, D. (2002). Transformational leadership effects on teachers' commitment and effort toward school reform. Journal of Educational Administration, 41(3), $228-256$. https://doi.org/10.1108/09578230310474403

Gökyer, N., \& Yılmaz, G. (2018). İlkokul yöneticilerinin dağıtılmış liderlik düzeyleri. Iğdır Üniversitesi Sosyal Bilimler Dergisi, 16, 409-442.

Grubb, W. N., \& Flessa, J. (2009). “A job too big for one”: Multiple principals and other nontraditional approaches to school leadership. In K. Leithwood, B. M. Mascall, \& T. Strauss (Eds.), Distributed Leadership According to the Evidence (pp.137-164). New York: Routledge.

Hammersley-Fletcher, L. (2004). Subject leadership in primary schools-Towards distributed practice. Education 3-13, 32(1), 26-30. https://doi.org/10.1080/03004270485200061

Harris, A. (2007). Distributed leadership: Conceptual confusion and empirical reticence. International Journal of Leadership in Education, 10(3), 315-325. https://doi.org/10.1080/13603120701257313

Harris, A. (2008). Distributed leadership: According to the evidence. Journal of Educational Administration, 46(2), 172-188. https://doi.org/10.1108/09578230810863253

Harris, A., \& Spillane, J. (2008). Distributed leadership through the looking glass. British Educational Leadership, Management \& Administration Society (BELMAS), 22(1), 31-34. https://doi.org/10.1177/0892020607085623

Heck, R. H., \& Hallinger, P. (2009). Assessing the contribution of distributed leadership to school improvement and growth in math achievement. American Educational Research Journal September, 46(3), 659-689. https://doi.org/10.3102/0002831209340042

Hoy, W. K., \& Miskel, C. G. (2010). Eğitim yönetimi teori, araştıma ve uygulama (Çev. Ed. S. Turan), Ankara: Nobel Yayın Dağıtım.

Hulpia, H., Devos, G., \& Keer, H. V. (2011). The relation between school leadership from a distributed perspective and teachers' organizational commitment: Examining the source of the leadership function. Educational Administration Quarterly, 47(5), 728-771. https://doi.org/10.1177/0013161X11402065 
Hulpia, H., Devos, G., \& Keer, H.V. (2010). The influence of distributed leadership on teachers' organizational commitment: a multilevel approach. The Journal of Educational Research, 103, 40-52. https://doi.org/10.1080/00220670903231201

Hulpia, H., Devos, G., \& Russell, Y. (2009). Development and validation of scores on the distributed leadership inventory. Educational and Psychological Measurement, 69(6), 1013-1034. https://doi.org/10.1177/0013164409344490

İnce, M., \& Gül, H. (2005). Yönetimde yeni bir paradigma: örgütsel bağlllık. Konya: Çizgi Kitabevi.

Jappinen, A. K. (2012). Distributed pedagogical leadership in support of student transitions. Improving Schools, 15(1), 23-36. https://doi.org/10.1177/1365480212439959

Kılıç, Ş., \& Burgaz, B. (2014). İlköğretim okulu öğretmenlerinin örgütsel yakınmacılık ve örgütsel bağlllık düzeyleri arasındaki iliş̧ki. Akdeniz Eğitim Araştırmaları Dergisi, 8(16), 17-34.

Korkmaz, E., \& Gündüz, H. B. (2011). İlköğretim okulu yöneticilerinin dağıtımcı liderlik davranışlarını gösterme düzeyleri. Kalem Eğitim ve Insan Bilimleri Dergisi, 1(1), 123-153. https://doi.org/10.23863/kalem.2017.4

Leithwood, K., Mascall, B., \& Strauss, T. (2009). New perspectives on an old idea. In K. Leithwood, B. Mascall, \& T. Strauss (Eds.), Distributed Leadership According to the Evidence (pp. 1-14). New York: Routledge. https://doi.org/10.4324/9780203868539

Li, C. (2011). Açık liderlik (Çev. G. Aksoy). İstanbul: Optimist Yayınları.

Lima, J. A. (2008). Department networks and distributed leadership in schools. School Leadership and Management, 28(2), 159-187.

Louis, K. S., Mayrowetz, D., Smiley, M., \& Murphy, J. (2009). The role of sensemaking and trust in developing distributed leadership. In A. Harris (Ed.), Distributed Leadership (pp. 157-180). London: Springer. https://doi.org/10.1007/978-1-4020-9737-9_9

O'Reilly III, C., \& Chatman, J. (1986). Organizational commitment and psychological attachment: The effects of compliance, identification, and internalization an prosocial behavior. Journal of Applied Psychology, 71(3), 492-499. https://doi.org/10.1037/0021-9010.71.3.492

Şama, E., \& Kolamaz, C. (2011). Destekleyici ve geliştirici liderlik özellikleri ile örgütsel bağl1lık arasındaki ilişki. Türk Eğitim Bilimleri Dergisi, 9(2), 313-342. Retrieved from https://dergipark.org.tr/tr/pub/tebd/issue/26100/275001

Schein, E. H. (1976). Örgütsel Psikoloji (Çev., A. Sağtür ve Ş. Özalp). Eskişehir: Eskişehir İktisadi ve Ticari İlimler Akademisi Basımevi.

Serin, M., \& Buluç, B . (2012). İlköğretim okul müdürlerinin öğretim liderliği davranışları ile öğretmenlerin örgütsel bağlılıkları arasındaki ilişki. Kuram ve Uygulamada Eğitim Yönetimi, 3(3), 435-459. Retrieved from https://dergipark.org.tr/tr/pub/kuey/issue /10323/126581

Silva, M. R. E. (2009). The Role of Distributed Leadership Quality EducationalOrganizations (Yayınlanmamış Doktora Tezi), California State University, Educational Leadership, Fresno.

Spillane, J. P., \& Diamond, J. B. (2007). A distributed perspective on and in practice. In J. P. Spillane, \& J. B. Diamond (Eds.), Distributed Leadership in Practice (pp. 146-166). New York: Teacher College Press.

Spillane, J. P., \& Orlina, E. C. (2005). Investigating leadership practice: Exploring the entailments of taking a distributed perspective. Leadership and Policy in Schools, 4, 157-176. https://doi.org/10.1080/15700760500244728

Spillane, J. P., Halverson, R., \& Diamond, J. B. (2004). Towards a theory of leadership practice: A distributed perspective. Journal of Curriculum Studies, 36(1), 3-34. https://doi.org/10.1080/0022027032000106726

Tabachnick, B. G., \& Fidell, L. S. (2013). Using multivariate statistics. Boston: Pearson.

Tadesse, E. F. (2019). Teachers' organizational commitment at secondary school in Addis Ababa, Ethiopia. International Journal of Education and Research, 7(4), 53-68.

Uçar, R. (2015). İlkokul müdürlerinin dăğtımcı liderlik davranışları ile ögretmenlerin motivasyon ve yaratıcllk düzeyleri arasındaki iliş̧ki Diyarbakır ili örneği (Yayınlanmamış doktor tezi). Dicle Üniversitesi, Sosyal bilimler Enstitüsü, Diyarbakır. 
Uçar, R., \& Dağl1, A. (2017). İlkokul müdürlerinin dağıtımcı liderlik davranışları ile öğretmenlerin motivasyon ve yaratıcılık düzeyleri arasındaki ilişki. Elektronik Sosyal Bilimler Dergisi, 16(60), 198-216. https://doi.org/10.17755/esosder.289661

Uğurlu, C. T., Sincar, M., \& Çınar, K. (2013). Ortaöğretim okulu öğretmenlerinin örgütsel bağlllık düzeylerine yöneticilerinin etik liderlik davranışlarının etkisi. Erzincan Üniversitesi Eğitim Fakültesi Dergisi, 15(1), 266-281.

Ünal Bozcan, E., \& Yalçınkaya, M. (2018). Temel eğitim kurumlarında yöneticilerin etik liderlik davranışları ile iletişim becerilerinin öğretmenlerin örgütsel bağlılık düzeyleri ile ilişkisi. Turkish Studies Educational Sciences, 13(27), 263-284. https://doi.org/10.7827/TurkishStudies.14344

Uygur, M., \& Yıldırım, A. (2011). İlköğretim okulu yöneticilerinin kültürel liderlik rolleri ile öğretmenlerin örgütsel bağlılığı arasındaki ilişki. Gazi Üniversitesi Endüstriyel Sanatlar Eğitim Fakültesi Dergisi, 27, $72-81$.

Yavuz, E., \& Tokmak, C. (2015). İşgörenlerin etkileşimci liderlik ve örgütsel bağlllık ile ilgili tutumlarına yönelik bir araştırma. Uluslararası İktisadi ve İdari İncelemeler Dergisi, 1(2), 17-34. Retrieved from https://dergipark.org.tr/tr/pub/ulikidince/issue/21625/232273

Zhang, J., \& Faerman, S. R. (2007). Distributed leadership in the development of a knowledge sharing system. European Journal of Information Systems, 16, 479-493. https://doi.org/10.1057/palgrave.ejis.3000694

Zırhlığlu, G., \& Atlı, M. (2011). Beden eğitimi bölümü özel yetenek sınavı puanlarının akademik başarı üzerindeki yordama geçerliği. Ĕgitim ve Bilim, 36(161), 176-185.

\section{Copyrights}

Copyright for this article is retained by the author(s), with first publication rights granted to the journal.

This is an open-access article distributed under the terms and conditions of the Creative Commons Attribution license (http://creativecommons.org/licenses/by/4.0/). 